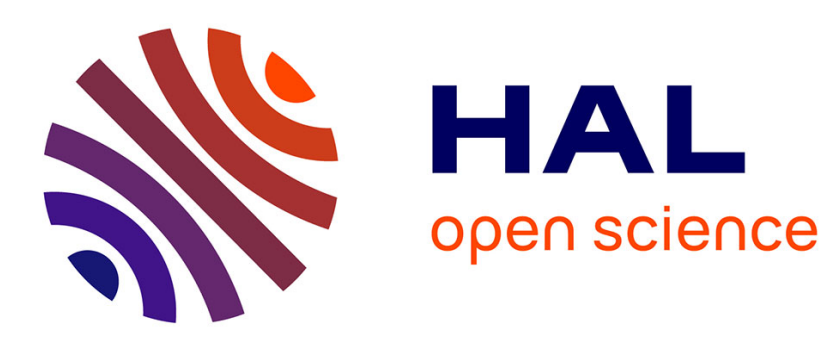

\title{
Judicial Investigations in Classical Islam
}

Mathieu Tillier

\section{To cite this version:}

Mathieu Tillier. Judicial Investigations in Classical Islam. Le récit criminel arabe / Arabic Crime Fiction, Harrassowitz Verlag, pp.17-30, 2021, 10.2307/j.ctv1h9djpf.4 . halshs-03163066

\section{HAL Id: halshs-03163066 \\ https://shs.hal.science/halshs-03163066}

Submitted on 9 Mar 2021

HAL is a multi-disciplinary open access archive for the deposit and dissemination of scientific research documents, whether they are published or not. The documents may come from teaching and research institutions in France or abroad, or from public or private research centers.
L'archive ouverte pluridisciplinaire HAL, est destinée au dépôt et à la diffusion de documents scientifiques de niveau recherche, publiés ou non, émanant des établissements d'enseignement et de recherche français ou étrangers, des laboratoires publics ou privés. 


\title{
Judicial Investigations in Classical Islam
}

\author{
Mathieu Tillier (Sorbonne Université / UMR 8167 Orient et Méditerranée)
}

\begin{abstract}
This paper starts from the observation that judicial investigations have long played a marginal role in Arabic literature. As a historian, and not a literature specialist, I question the institutional background of such marginalization. It appears that, although some judges practiced investigations in the early days of Islam, Muslim jurists abandoned this practice towards the end of the Umayyad period because of its potential arbitrariness. The qadi's justice system transferred the entire investigation process on the reliability of witnesses. Only secular judicial institutions (police, mazālim) continued to seek the truth beyond appearances. However, the poor reputation of police officers also led to their literary marginalization.
\end{abstract}

Keywords: Judges; qadis; courts; witnesses; procedures; investigations

Investigation is at the heart of contemporary crime fiction. When the investigator is a police officer, he usually acts under the supervision of an examining magistrate or a prosecutor, in accordance with contemporary Western judicial systems. The investigation represents the first step in the judicial processing of a case, before its conclusions are used against the defendant during his trial. Therefore, magistrates are common characters in police literature. However, not all judicial systems operate in the same way and police literature is not equally represented in all cultural traditions. As a fan of crime fiction, I have long been wondering why contemporary Arabic fiction, until recently, only marginally explored this genre. Could one speculate that the scarcity of the police genre might be somehow related to classical Arabic literary tradition? I have no ambition to answer this question, which I leave to literature specialists. For my part, I will only try and show in this paper why the classical Islamic judicial system leaves very little room for investigations. This may explain why classical Arabic literature could hardly develop a "police" genre in connection with the main judicial institution, as evidenced by the anthology of Arabic crime literature from the Abbasid period published by Katia Zakharia, which includes only a few qadis. ${ }^{1}$

Like all other areas of Islamic law (fiqh), judicial procedures in classical Islam are characterized by a high degree of normative pluralism. The numerous Sunni, Shi'i and Khariji legal schools (madhab-s) promote a certain variety of solutions for each procedural issue, and each school may also consider different rules. Despite such pluralism, all schools agree on a series of basic principles that represent a common ground for judicial proceedings. These rules were the outcome of tentative solutions and experiments that took place during the first century and a half of Islam. Revisiting the first developments of judicial procedures in Islam is therefore crucial to understand the functioning of the judiciary and the role of investigation in the judicial process at a time when adab began to develop - that is, from the second half of the eighth century CE and, most importantly, from the ninth century CE onwards.

\footnotetext{
${ }^{1}$ Only three habar-s out of twenty-eight feature a qadi (an anonymous one, and the famous Iyās b. Mu 'āwiya for the other two). K. Zakharia, Nouvelles policières du monde abbasside, Paris, Pocket, 2008, p. $42-45$ (habar 7), 4649 (habar 8), 50-52 (habar 9).
} 
M. Tillier, «Judicial Investigation in Classical Islam », dans Katia Ghosn et Benô̂t Tadié (éd.), Le récit criminel arabe / Arabic crime fiction, Harrassowitz, Wiesbaden, 2021, p. 17-30.

In the following pages, I rely on the work I have carried out over the past decade, the results of which I exposed in detail in my book L'invention $d u$ cadi. ${ }^{2}$ I will summarize the major chronological developments of judicial procedures, and attempt to explain why the experiments conducted mainly in the first half of the eighth century led, in qadis' courts, to marginalizing the hypothetical deductive system used in investigations.

\section{THE ARCHAIC PERIOD: SOlOMON VERSUS DAVID}

A judge may follow two distinctive procedural methods, which he may also combine. The first possible procedure is an inquisitorial one, in which a judge or a third party (like a police officer) carries out an investigation, aimed at discovering the truth about a case. This investigation may involve a search for clues or evidence, or the questioning of parties or witnesses. The court renders a judgement on the basis of the evidence gathered during the investigation. The second procedure is an adversarial one. It does not rely on any investigation, but rather on the words of the litigants or their representatives. Unlike the inquisitorial procedure, in which the judge plays an active role, the adversarial procedure limits his role to that of an impartial listener, responsible for deciding after examining the evidence provided by the litigants to support their allegations.

The functioning of justice in the first decades following Muhammad's death is very poorly known. It gradually comes out of the darkness towards the end of the seventh and the beginning of the eighth centuries CE. Literary sources referring to legal practices during that early period suggest that the judicial system, whose main actor was the qadi, was not a homogeneous one. From one region of the empire in formation to another, in different cities, procedures varied according to local traditions and experiments conducted by judges. A tension existed between the two aforementioned types of procedures, inquisitorial and adversarial, particularly in Iraq, which is the best-documented province for that time.

In the city of Bașra, some qadis were inclined to follow an inquisitorial procedure. This was particularly the case of the judge Iyās b. Mu 'âwiya (d. c. 121/739) who, at the end of the 710s, dispensed justice on the basis of circumstantial evidence, unlike most of his contemporaries. This qadi was later praised in literary sources for his outstanding observing skills, which led some modern researchers to compare him to Sherlock Holmes. ${ }^{3}$ On some occasions, he carried out real investigations aimed at uncovering the truth. His investigations did not take him outside the courtroom, however, and he achieved his goals above all through clever questionings of the litigants, and pushed them to betray themselves. For example, he asked two women, who argued over a wool ball, what the yarn was wrapped around. The woman who answered correctly won the case. ${ }^{4} \mathrm{He}$ is reported to have determined the rightful owner of a coat by having the litigants' hair searched for threads. ${ }^{5}$ He was also able to discover a fraud by examining dates minted on disputed coins. ${ }^{6}$

\footnotetext{
${ }^{2}$ M. Tillier, L'invention du cadi. La justice des musulmans, des juifs et des chrétiens aux premiers siècles de l'Islam, Paris, Publications de la Sorbonne, 2017.

${ }^{3}$ F. Malti-Douglas, "The Classical Arabic Detective," Arabica, 35 (1988), p. 68-9.

${ }^{4}$ Wakī', Ahbār al-quḍāt, ed. 'Abd al- 'Azīz Mușțafā al-Marāḡì, Cairo, Maṭba 'at al-sa'āda, 1947-1950, I, p. 332. Cf. al-Balādurī, Ansā̄b al-ašrāf, ed. Suhayl Zakkār and Riyāḍ Ziriklī, Beirut, Dār al-fikr, 1996, XI, p. 339-40.

${ }^{5}$ Al-Balādurī, Ansāb al-ašrāf, XI, p. 338; Wakī`, Ahbāar al-quḍāt, I, p. 338-9.

6 Al-Balādurī, Ansāa al-ašrāf, XI, p. 341; Wakī', Ahbārr al-quḍāt, I, p. 342. The main reports about Iyās b. Mu'āwiya were later repeated by Ibn Qayyim al-Ǧawziyya, al-Ṭruq al-ḥukmiyya fi l-siyāsat al-šar 'iyya, ed.
} 
The strategies Iyās b. Mu âwwiya employed to discover the truth sometimes led Muslim scholars to describe his justice as a "Solomonian" one, similar to the Biblical Solomon's tricks. His justice relied on his ability to draw conclusions from the observation of people and of their behavior. This faculty, which ancient Arabs called firāsa (insight), was considered a form of "inductive divination", and the basis of physiognomony. ${ }^{7}$

Fig. 1. The inquisitorial procedure, or "Solomon's judgment"

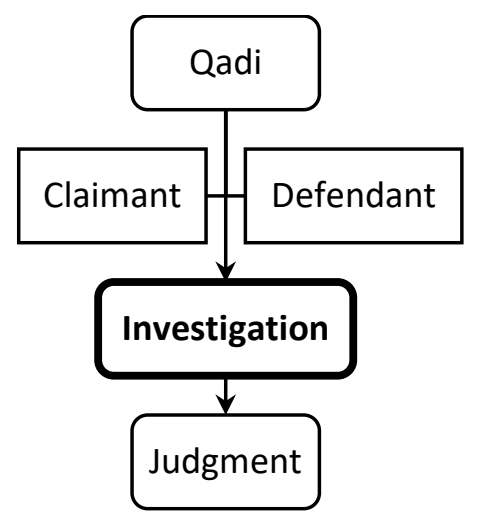

In Küfa, as was most often the case in other Islamic cities, judges usually followed an adversarial procedure. Qadis did not investigate or seek the truth on the basis of circumstantial evidence or clues. Their decisions relied on three types of evidence. The defendant's confession, called iqrār or i 'tirâf, automatically resulted in his conviction. If the defendant did not confess, the judge would hear witnesses. Testimonial evidence, which became known as bayyina ("obvious evidence"), was gradually restricted to the plaintiff (the accuser), who was to produce two witnesses considered as just ( $a d l$ ). In the absence of witnesses, the qadi could request an oath from the defendant, who won the trial if he swore of his innocence and might lose it if he did not. Some jurists also accepted that a plaintiff who could only produce one witness also take an oath regarding the truthfulness of his claims. ${ }^{8}$

The advantage of this adversarial procedure was that it left less room for a judge's personal interpretation. The qadi was supposed to stick to the appearances provided by the three categories of evidence and not to try and discover the hidden truth. If he rendered a judgment according to appearances, he did not commit any injustice even if his decision was wrong, provided that he had properly followed the procedure. While the inquisitorial procedure was associated with the figure of Solomon, the adversarial procedure was called fașl al-hitāa b, a Qur'anic expression associated with that of his father David, ${ }^{9}$ a king and prophet to whom God had granted wisdom (hikma) and "the art of judging" (fașl al-hițāb). ${ }^{10}$

Muhammad Ḥāmid al-Faqī, Cairo, Maṭba at al-sunna al-muhammadiyya, 1953, p. 31-34. See also Ibn Qutayba, 'Uyūn al-aḩbār, Cairo, Dār al-kutub al-mișriyya, 1996, I, p. 74; al-Balādurīi, Ansāa al-ašrāf, XI, p. 343; Wak̄̄', Ahbār al-quḍāt, I, p. 327.

7 On "Solomon's judgment”, see M. Tillier, L'invention du cadi, p. 360-366.

${ }^{8}$ These procedures underwent a complex evolution, the details of which are explained in M. Tillier, L'invention du cadi, chap. 3 .

${ }^{9}$ Wakī', Ahbāar al-qud̄àt, II, p. 317.

${ }^{10}$ Qur'an, 38:20. 
Fig. 2. The adversarial procedure, or "David's judgment"

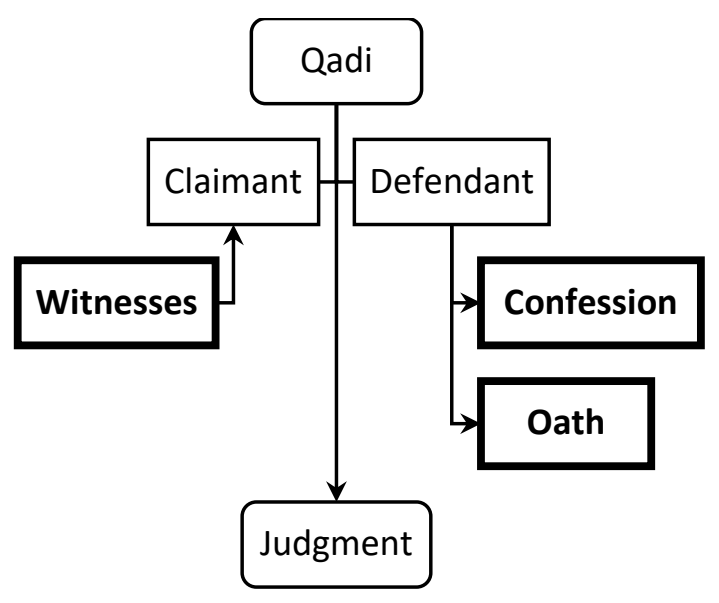

\section{DAVID AND KALILLA WA-DIMNA, OR THE VICTORY OF THE ADVERSARIAL PROCEDURE}

"David's judgment", that is the adversarial procedure, appeared the most rigorous way to adjudicate, for it relied on a precise and well-tested method. In the middle of the eighth century, Muslim jurists accepted it unanimously, and the maxim on which it rested was gradually backprojected on the Prophet. ${ }^{11}$ A report attributed to 'Alī, and later quoted by the Ismaili qadi alNu'mān (d. 363/974) in his Da 'á'im al-islām, illustrates why the Davidian procedure appeared more reliable than Solomon's investigations. David complained to God that, unlike Him, he did not have the omniscience that would have allowed him to dispense a perfect justice. God ordered him to "render justice between people based on oaths and bayyina-s." However, David insisted that God, relying on His knowledge, should reveal to him the judgments he should pass. God accepted his request and, on three occasions, ordered him to issue verdicts that were apparently unjust and arbitrary, which angered his people. God then explained to David that, in all three cases, the apparent victim was actually the culprit, although no evidence could ever prove it. David eventually agreed to rely on the legal proofs specified by God, on the basis of which he would punish apparent wrongdoers, and left to God the task of judging them according to the truth on Judgment day. ${ }^{12}$

Although it was reported by an Ismaili author, this story reflects a common understanding among most Muslim jurists. Since only God knows the inner truth of everything, a judge does not need to conduct an inquiry that could lead to false conclusions. He should rather stick to appearances and God will judge the true culprits at the end of times. Conversely, "Solomon's judgment", which relied on inquisitorial strategies, did not appear attainable by everyone. Not all judges could claim to possess Iyās b. Mu'āwiya's skills, which amounted to a form of clairvoyance. His lack of a definable method to reach the truth probably appeared as a problem to many Muslims. Although Iyās b. Mu 'āwiya became a legend thanks to his Solomonian gifts

\footnotetext{
${ }^{11}$ R. Brunschvig, "Le système de la preuve en droit musulman," in Études d'islamologie, Paris, Maisonneuve et Larose, 1976, II, p. 209; Ch. Melchert, "The History of the Judicial Oath in Islamic Law," in M.-Fr. Auzépy and G. Saint-Guillain (ed.), Oralité et lien social au Moyen Âge (Occident, Byzance, Islam) : parole donnée, foi jurée, serment, Paris, AACHCByz, 2008, p. 309, 322.

${ }^{12}$ Al-Qāộ̃ al-Nu 'mān, Da'ā'im al-islām, ed. 'Āsif b. 'Alī Aș̣gar Fayḍ̂̄, Cairo, Dār al-ma ārif, 1951, II, p. 518-520. Cf. al-Kulaynī, Furū' al-kāfì, Beirut, Dār al-ta'āruf, 1993, V, p. 454-455, 461-462, 472-473.
} 
and caused much admiration, such justice was based on a form of empiricism that could easily degenerate into arbitrariness.

The use of firāsa in the judicial field was later vehemently denounced in the Arabic version that Ibn al-Muqaffa' (active in particular in Bașra, d. c. 139/756) composed of Kalīla waDimna. In the story of Dimna's trial - often seen as an addition to the original Pehlvi text by Ibn al-Muqaffa ${ }^{13}$ - the lion's table master (șăhib al-mā'ida), talking about the accused jackal, attacks "this miserable man whose [body] bears the stigmata of evil ('alāmāt al-šarr) and the signs of depravation" before adding: "And scholars do not ignore how to judge such men!"14 After the table master has described these signs and their meaning to the chief judge, Dimna launches into a long diatribe in which he condemns the wrong use of such physiognomony for judicial purposes, and proves to the king that justice based on inherited physical characteristics can only lead to arbitrariness. ${ }^{15}$ The judge cannot therefore retain such evidence, and he only condemns Dimna after two witnesses have testified, in accordance with the procedure that Islam generally accepted at the time Ibn al-Muqaffa ' was writing. ${ }^{16}$ "David's judgment," which was particularly promoted in Küfa and did not depend on any unpredictable kind of insight, but rather on a rigorous assessment of appearances as revealed by legal evidence (testimony and oath), eventually prevailed and became a long-standing feature of Islamic law.

\section{TOWARDS A NEW TYPE OF INVESTIGATION}

Does this mean that investigations disappeared totally from the judicial process? This was not the case. The canonization of the adversarial procedure rather shifted the investigation from the veracity of the facts to another issue, namely, the truthfulness of the words spoken at the hearing. In other judicial systems, such as that of West-Syrian Christians before Islam, the judge investigated the reliability of the litigants in an attempt to determine which one was most likely to tell the truth. ${ }^{17}$ Yet, Muslim jurists seem never to have considered any moral inquiry regarding litigants, because their word appeared suspicious as a principle. Anyone could lie to defend himself, and besides, an individual's honesty did not compensate for his failing memory or prevent him from committing a mistake. However, the adversarial procedure gave a key role to witnesses, and their reliability became increasingly subject to investigations.

Such investigations developed gradually. ${ }^{18}$ In the Umayyad period, judges did not examine the reliability of witnesses on a systematic basis. They only questioned their reliability if challenged by the adversary of the party in whose favor they testified ${ }^{19}$. Yet, there was generally no investigation as such. Sometimes the judge would simply interrogate the witnesses about each other. ${ }^{20}$ Some qadis asked unknown witnesses to bring someone who could testify to their

\footnotetext{
${ }^{13}$ F. de Blois, Burzōy's Voyage to India and the Origin of the Book of Kalīlah wa Dimnah, London, Royal Asiatic Society, 1991, p. 14. For an opposite view, see J. Jany, "The Origins of the Kalīlah wa Dimnah: Reconsideration in the Light of Sasanian Legal History," Journal of the Royal Asiatic Society, Series 3, 22 (2012), p. 518.

${ }^{14}$ Ibn al-Muqaffa', Kalīla wa-Dimna, in L. Cheikho (ed.), La version arabe de Kalîla et Dimna d'après le plus ancien manuscrit arabe daté, Beirut, Imprimerie catholique, 1905 p. 119.

${ }^{15}$ Ibn al-Muqaffa', Kalīla wa-Dimna, p. 119-120.

${ }^{16}$ Ibn al-Muqaffa', Kalīla wa-Dimna, p. 124.

${ }^{17}$ M. Tillier, L'invention du cadi, p. 427-428.

${ }^{18}$ For a detailed account of this evolution, see M. Tillier, L'invention du cadi, p. 304-316.

${ }^{19}$ See for example Wakī' , Ahbār al-quḍāt, I, p. 72, 284; II, p. 8, 13, 237, 254; Ibn Ḥazm, al-Muhallā, Cairo, Idārat al-țibā'a al-munīriyya, 1352 H., IX, p. 394, 416.

${ }^{20} \mathrm{Wak}^{`}{ }^{\prime}$, Ahbār al-qud̄àt, I, p. 194; II, p. 87.
} 
M. Tillier, «Judicial Investigation in Classical Islam », dans Katia Ghosn et Benô̂t Tadié (éd.), Le récit criminel arabe / Arabic crime fiction, Harrassowitz, Wiesbaden, 2021, p. 17-30.

good morality. ${ }^{21}$ A large number of witnesses could also compensate for their lack of reliability. Therefore, until the beginning of the eighth century, in cities such as Bașra and Medina, the party that brought the largest number of witnesses won the case. ${ }^{22}$ However, this encouraged both parties to bring along as many witnesses as possible, which could eventually block the lawsuit. Towards the end of the Umayyad period, the restriction of the bayyina to two witnesses produced by the plaintiff prevented such escalations. It was no longer possible to compensate for the poor reliability of some witnesses with a large number of testimonies. Producing two or ten witnesses did not change the outcome. With two reliable witnesses, a claimant would now to win his case.

This led qadis to multiply innovations during the second half of the eighth century in order to verify the reliability of witnesses, conceived in terms of social and religious respectability ( $a d \bar{a} l a$ ). As a first step, some judges conducted their own investigations into the reputation of dubious witnesses, by interviewing their neighbors for example. ${ }^{23}$ However, the consolidation of the judiciary during the Abbasid period allowed them to hire additional staff. Beside their clerks and other court officials, qadis were able to appoint a professional investigator, called șăhib al-masā'il ("master of questions") or muzakkī ("investigator"), an office that a qadi of Küfa had apparently invented during the Umayyad period without it being taken over by his immediate successors. ${ }^{24}$ This institution was resumed and developed under the Abbasids, ${ }^{25}$ and was introduced in various provinces, particularly in Egypt. ${ }^{26}$

Attaching a group of witnesses to the court was the last step in this evolution. Such groups appeared first in Egypt at the turn of the ninth century, then in Iraq during the second half of the ninth century. ${ }^{27}$ Relying on such an instrumental body of witnesses limited the number of investigations. Once a qadi had accepted them as truthful, he only needed to renew investigations about them about every six months. ${ }^{28}$ Individuals were encouraged to ask them to attest to their legal acts, which avoided increasing the number of investigations on all the unknown people who could otherwise have been brought forward as witnesses. Some litigants probably continued to use witnesses from outside this circle. However, their testimony would more likely be rejected and many people now preferred asking professional witnesses already accredited by the court.

\footnotetext{
${ }^{21}$ Wakī̄, Ahbār al-quḍ̄t, II, p. 46, 416; III, p. 8.

${ }^{22}$ See for example Wakī', Ahbār al-quḍāt, I, p. 304, 369; II, p. 19, 42, 127, 135, 140; 'Abd al-Razzāq al-Ṣan 'ānī', Mușannaf 'Abd al-Razzāq, ed. Habīb al-Raḥmān al-A żamī, Beirut, al-Maktab al-islāmī, 1983, VIII, p. 279-80; Ibn Abī Shayba, al-Muṣannaf, ed. Ḥamad b. 'Abd Allāh al-Ğum'a and Muhammad b. Ibrāhīm al-Luḥaydān, Riyad, Maktabat al-rušd, 2004, VII, p. 411.

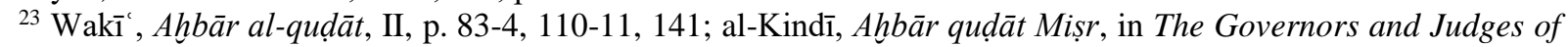
Egypt, ed. Rhuvon Guest, Leiden, Brill, 1912, p. 351, 361, 437

${ }^{24}$ Wak̄ì', Ahbār al-quḍāt, III, p. 106. Cf. Ibn Sa 'd, al-Ṭabaqāt al-kubrā, Beirut, Dār Șādir, 1968, VI, p. 351.

${ }^{25}$ Wakī', Ahbār al-quḍāt, III, p. 134

${ }^{26}$ Al-Kindī, Ahbār quḍāt Miṣr, p. 385. See M. Tillier, "Scribes et enquêteurs. Note sur le personnel judiciaire en Égypte aux quatre premiers siècles de l'hégire", Journal of the Economic and Social History of the Orient, 54 (2011), p. 379-81.

${ }^{27}$ Al-Kindī, Ahbār quḍāt Miṣr, p. 386, 389, 392, 396; al-Ṭūsī, al-Mabsūt fì fiqh al-imāmiyya, Beirut, Dār al-kitāb al-islāmī, 1992, VIII, p. 111. See E. Tyan, Histoire de l'organisation judiciaire en pays d'Islam, $2^{\text {nd }}$ edition, Leiden, Brill, 1960, p. 239-40; Cl. Cahen, “À propos des shuhūd,” Studia Islamica, 31 (1970), p. 76; M. Tillier, "Les réseaux judiciaires en Iraq à l'époque Abbasside," in D. Coulon, Ch. Picard, D. Valérian (ed.), Espaces et réseaux en Méditerranée, vol. II. La formation des réseaux, Paris, Bouchène, 2010, p. 102-3.

${ }^{28}$ Al-Kindī, Ahbāar quḍāt Miṣr, p. 422.
} 
Fig. 3. The classical adversarial procedure, including investigation into witnesses

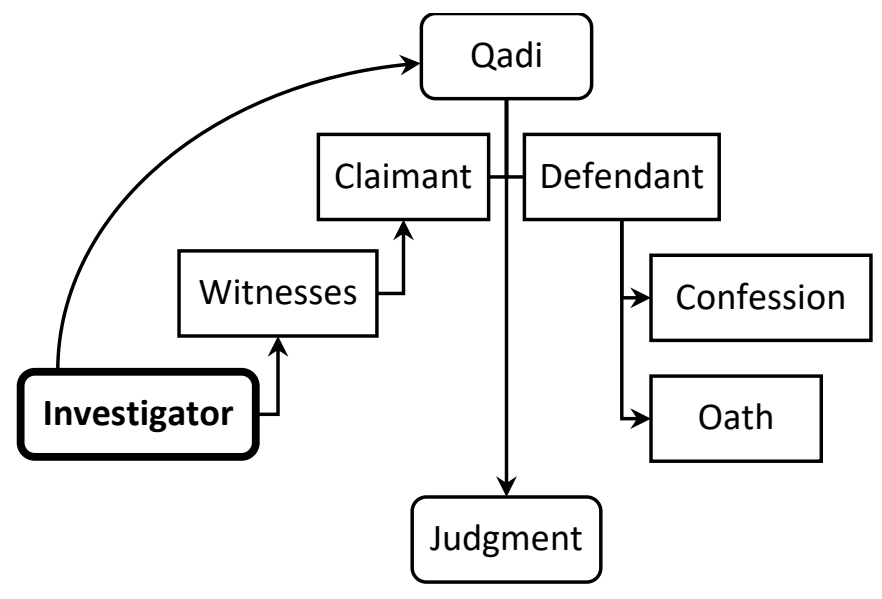

The victory of the adversarial procedure in the eighth century therefore limited the qadi's role to listening to testimonial evidence and oaths. He could still take into consideration material evidence. However, an expert needed to present it orally, as a testimony. ${ }^{29}$ The strictly adversarial nature of the proceedings was not challenged until the fourteenth century. Ibn Qayyim al-Jawziyya (d. 751/1350), in his endeavor to resurrect early Islamic practices, noted that the word bayyina had a less restrictive meaning in the Qur'an than in traditional court proceedings, for the term referred in the sacred book to any form of "proof." He therefore invited judges to take into consideration clues (qarā'in), signs (amārāt) and circumstantial evidence (dalālat al-ḥâl), that is to exercise their firāsa following the example of Iyās b. Mu'āwiya. ${ }^{30}$ Such a critical approach to the classical adversarial procedure eventually led to the reintroduction of inquisitorial elements and, during the Ottoman period, to the development of investigation methods under the supervision of judges.

\section{CONCLUSION}

Islamic judicial procedures left room for investigations in the early eighth century. However, Muslim jurists soon discarded such a method, or at least restricted it to witnesses' reputation. According to the underlying principle of this evolution, only God knew the truth, and only a few exceptionally skillful people could expect to approach it. Human justice should therefore rely on appearances. Even investigations into witnesses were probably rather superficial. For a qadi, the main issue was not to know how they behaved behind the walls of their homes, but merely to ensure that they complied with Islam's religious obligations, that they were good neighbors and did not cause any scandal. God alone knew what appearances could hide. This conception of justice did not preclude a longstanding fascination and admiration for the first investigators of Islam. Iyās b. Mu 'âwiya thus became the archetype of the investigator and the hero of stories praising his observation skills and often repeated in adab literature.

\footnotetext{
${ }^{29}$ On this issue, see J.-P. Van Staëvel, "Savoir voir et le faire savoir : l'expertise judiciaire en matière de construction, d'après un auteur tunisois du 8/XIV siècle," Annales Islamologiques, 35 (2001), p. 629.

${ }^{30}$ Ibn Qayyim al-Ğawziyya, al-Ṭruq al-hukmiyya, p. 12, 24. See B. Johansen, "Signs as Evidence. The Doctrine of Ibn Taymiyya (1263-1328) and Ibn Qayyim al-Jawziyya (d. 1351) on Proof," Islamic Law and Society, 9 (2002), p. 187.
} 
It should be noted, however, that the judicial system was not entirely affected by this conception of justice. "Secular" justice exercised by representatives of the political-military apparatus followed another evolution. Caliphs, viziers and governors dispensed justice in mazālim courts, a high jurisdiction that embodied the ruler's justice. Police chiefs (shurța) also had their own court. However, Islamic law did not regulate the proceedings of any of these courts and the procedural rules drawn up by fuqah $\bar{a}$ ' were not binding there. The police, in particular, continued to implement investigative procedures to find the perpetrators of crimes and misdemeanors. As a result of their ability to conduct investigations, the police and governor's courts became the main venues for criminal cases, while qadi courts specialized in civil matters. Governors and caliphs are therefore more often associated with investigations than qadis in classical Arabic literature. ${ }^{31}$ Unfortunately, historical sources provide little information on the functioning of police courts, perhaps in part because police officers, who were regarded as violent soldiers, were usually unpopular in the scholarly circles that produced our texts. ${ }^{32}$ Because of this lack of consideration, adab literature offered a smaller place to police officers who conducted daily investigations than it did to the qadis. Should one recognize here the origins of the marginal nature of police investigation in contemporary literature? Once again, I do not have the ambition to answer this question. I might simply add that it may be no coincidence if one of the precursors of Arabic crime novels, the famous Yawmiyāt nā 'ibin fi laryā $f$ of Tawfìq al-Hakīm, features a magistrate (and not a policeman), and investigations actually play a minor role in the storyline.

\footnotetext{
${ }^{31}$ See for example K. Zakharia, Nouvelles policières, p. 30-33 (habar-s 3, 4), 38-41 (habar 6), 54-71 (habar-s 10, $12,13)$, etc. On the mazālim jurisdiction, see M. Tillier, "The Mazālim in Historiography," in A.M. Emon and R. Ahmed (ed.), Oxford Handbook of Islamic Law, Oxford University Press, Oxford, 2018, p. 357-380.

${ }^{32}$ See M. Tillier, Les cadis d'Iraq et l'État abbasside, Damascus, Ifpo, 2009, p. 660-661.
} 